\title{
Bed-Material Entrainment and Associated Transportation Infrastructure Problems in Streams of the Edwards Plateau, Central Texas
}

The Texas Department of Transportation (TxDOT) commonly builds and maintains low-water crossings (LWCs) over streams (fig. 1) in the Edwards Plateau in Central Texas. LWCs are low-height structures, typically constructed of concrete and asphalt, that provide acceptable passage over seasonal rivers or streams with relatively low normal-depth flow. They are designed to accommodate flow by roadway overtopping during highflow events. The streams of the Edwards Plateau are characterized by cobble- and gravel-sized bed material and highly variable flow regimes. Low base flows that occur most of the time occasionally are interrupted by severe floods. The floods entrain and transport substantial loads of bed material in the stream channels. As a result, LWCs over streams in the Edwards Plateau are bombarded and abraded by bed material during floods and periodically must be maintained or even replaced.

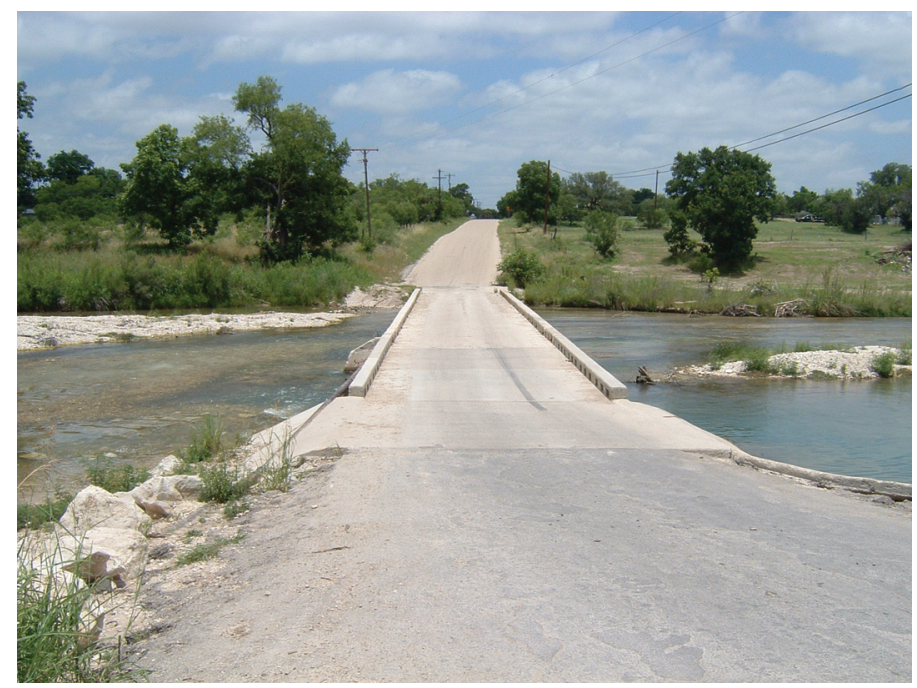

Figure 1. Flatrock Crossing of the South Llano River in Kimble County, Texas.

This research study, done by the U.S. Geological Survey (USGS), in cooperation with TxDOT, was designed to quantify the potential for bed-material entrainment in selected streams in the Edwards Plateau as part of TxDOT Research Project 0-4695: Guidance for Design in Areas of Extreme Bed-Load Mobility. The study included geographic information system (GIS) analyses, floodfrequency analyses, field investigations, and computations of bed-material entrainment. Results are expected to complement numerical and physical modeling of bed-material mobility at Texas Tech University, the University of Houston, and Lamar University, all collaborators on this study, and to facilitate LWC design and assignation of risk to channel reaches subject to bed-material mobility.

\section{Methods Applied to Quantify Bed- Material Entrainment}

Visualization of the distribution of channel slopes at watershed and channel-reach scales is important for TxDOT engineers and other practitioners. Accordingly, channel slopes were mapped in the study area (fig. 2) using GIS. An example of a final slope map for the North Llano River subbasin is shown in figure 3.

An alternative method for visualization of channel slope involves longitudinal profiles. A longitudinal profile is a graph of channel-bed elevation with downstream distance for one stream. Longitudinal profiles can be used to (1) estimate channel slope for reaches that were not surveyed in the field or (2) locate relatively steep channel reaches where greater energy conditions exist for sediment entrainment and transport. Longitudinal profiles for selected streams in the study area were created using GIS. One example of a longitudinal profile is shown in figure 4 for the Llano River.

Bed-material entrainment can be computed for a site using GIS- and field-collected data. However, the only way to estimate the temporal frequency of bed-material entrainment is through association with flood frequency. For this reason, partial-duration flood-frequency analyses were done for selected gaging stations in the study area. The partial-duration series uses discharges of measured and estimated flood peaks above a designated threshold (base discharge). In combination with flood-frequency analyses, field surveys of cross-sectional channel geometry and bed-material particle size (fig. 5) were done to obtain the data to apply equations that quantify bedmaterial entrainment. 


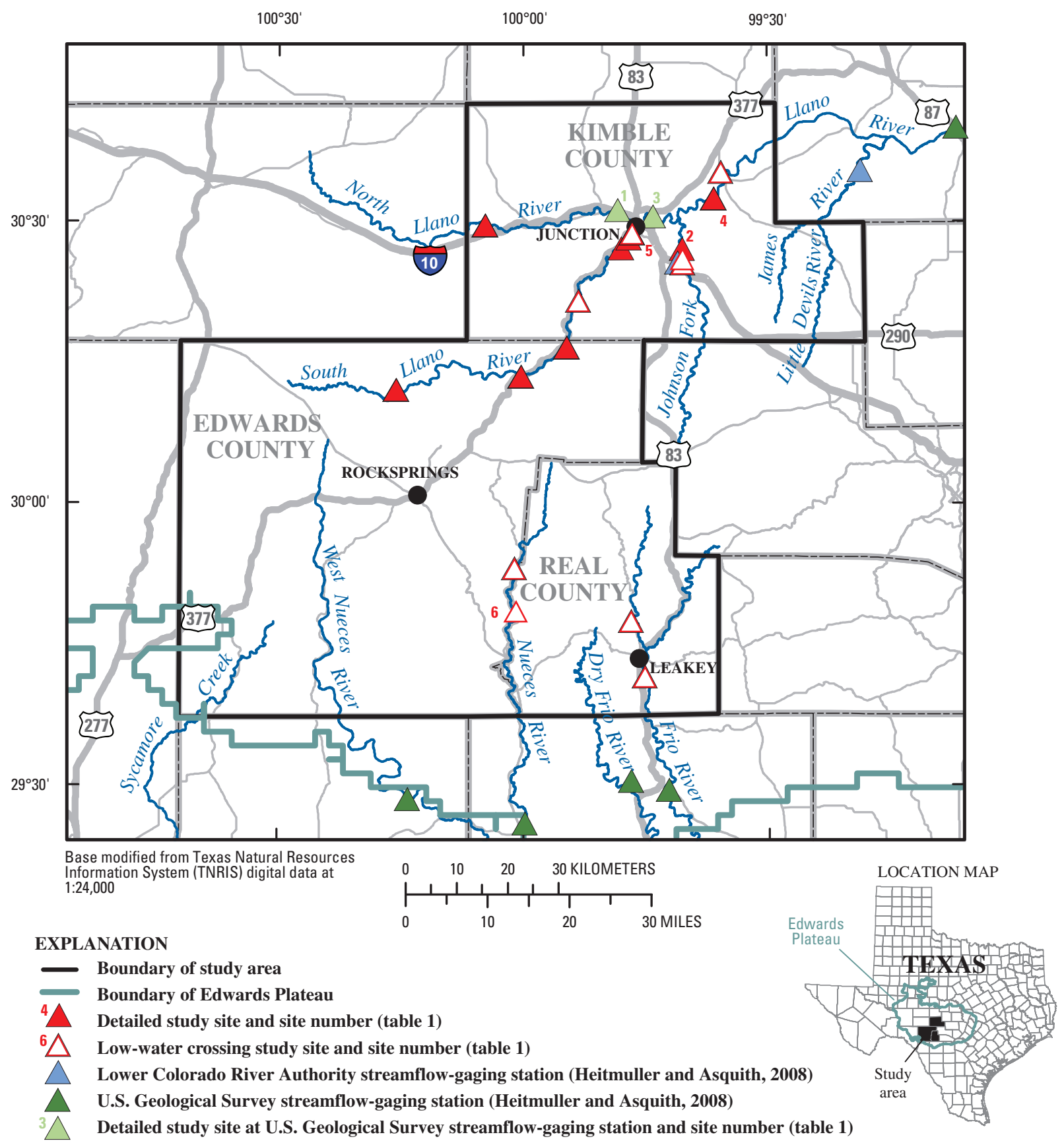

Figure 2. Location of study area-Edwards, Kimble, and Real Counties, Texas, and vicinity.

\section{Bed-Material Entrainment Potential}

Bed-material entrainment refers to the incipient motion of sediment along a channel bed. During low-flow conditions in cobble- and gravel-bed streams, coarse bed material remains in place (fig. 6). However, moderate- to high-flow conditions exert greater stresses on the channel bed, and coarse bed material initially mobilizes at a critical shear stress, which can be associated with flow depth, flow velocity, and discharge. Computations of bedmaterial entrainment (table 1) rely on channel-geometry and particle-size data.
The computed critical shear stresses, streamflows, and return periods for bed-material entrainment serve only as a predictive model for bed-material entrainment in the study area. The results thus provide limited guidance for predicting actual bed-material entrainment, but some interpretations are possible: An average of 1 year occurs between flows that initially entrain bed material as large as the median particle size, and an average of 1.5 years occurs between flows that completely entrain bed material as large as the median particle size. The return periods tend to match qualitative observations in the study area. Floods and bed-material entrainment are not uniformly distributed through time. Floods and 

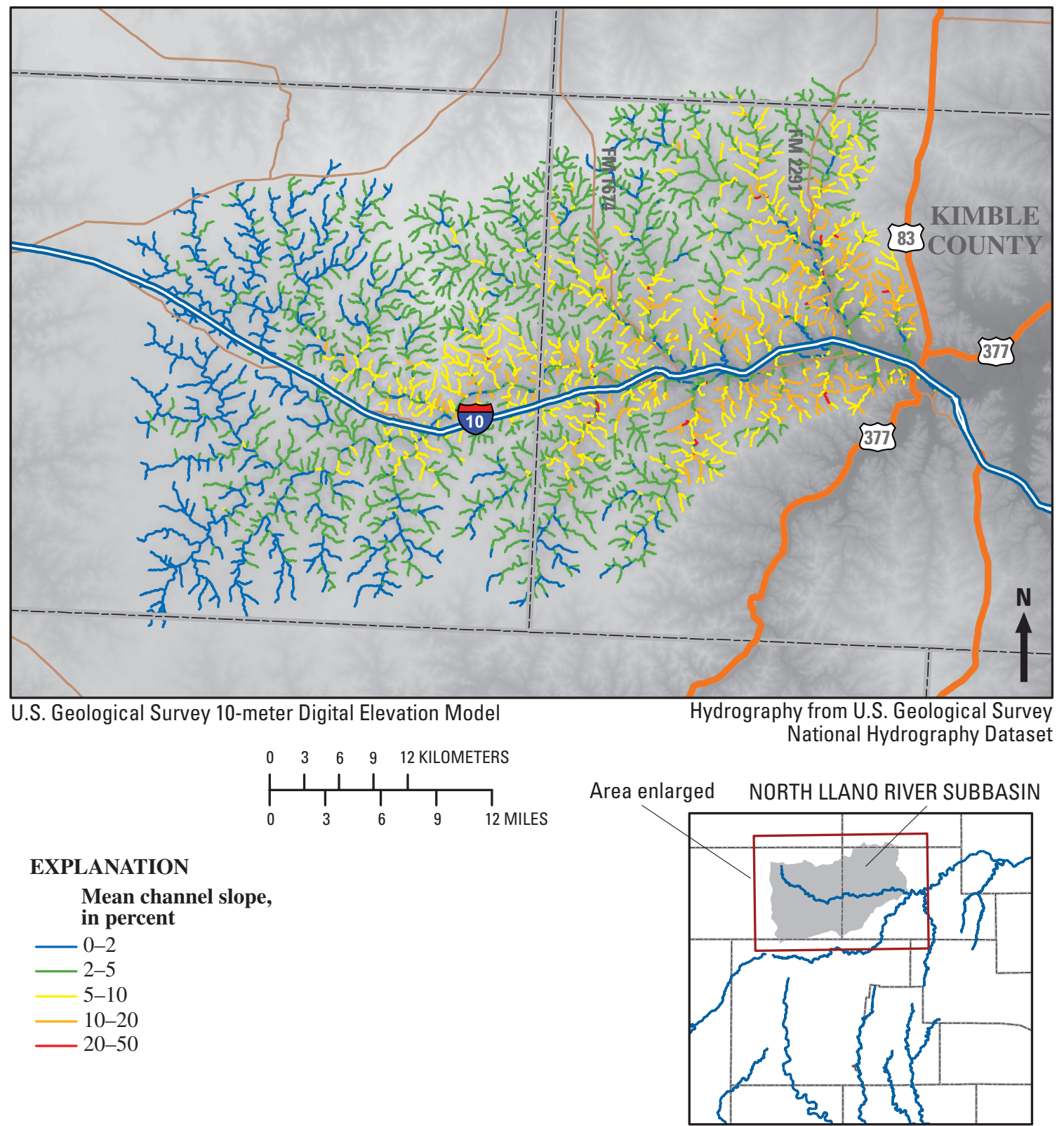

INDEX MAP OF STUDY AREA

Figure 3. Channel slope of the North Llano River subbasin, Kimble County, Texas, and vicinity.

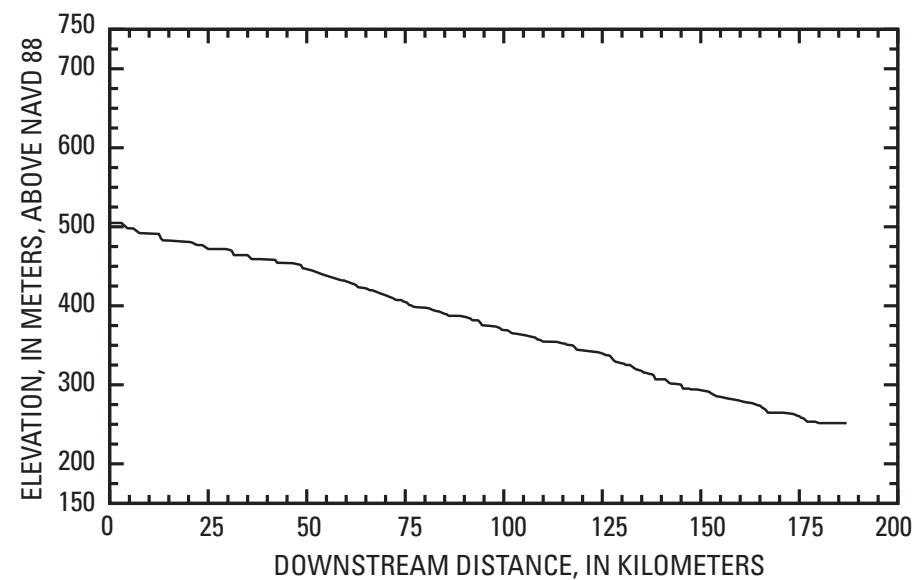

associated bed-material entrainment frequently occur with decreased intervals of time between them during wet periods; and they occur less frequently during relatively normal to dry periods. The frequent entrainment of cobble- and gravel-sized bed material underscores the difficulties TxDOT faces with maintenance of LWCs in the study area.

Figure 4. Longitudinal profile of the Llano River, Kimble County, Texas, and vicinity. 
Table 1. Computations for bed-material entrainment and return periods at sites in Edwards and Kimble Counties, Texas.

$\left[\mathrm{d}_{50}\right.$, descriptor that represents diameter at which 50 percent of sample is finer than; $\tau_{\mathrm{c}}$, critical shear stress; $\mathrm{N} / \mathrm{m}^{2}$, newtons per square meter; $\mathrm{Q}$, streamflow; $\mathrm{m}^{3} / \mathrm{s}, \mathrm{cubic}$ meters per second; $\mathrm{ft}^{3} / \mathrm{s}$, cubic feet per second; yr, years; <, less than]

\begin{tabular}{|c|c|c|c|c|c|c|c|c|}
\hline $\begin{array}{l}\text { Study } \\
\text { site } \\
\text { number } \\
\text { (fig. 2) }\end{array}$ & Study site & $\begin{array}{l}\text { Cross } \\
\text { section }\end{array}$ & $\begin{array}{c}d_{50} \tau_{c} \\
\text { initial } \\
\left(N / m^{2}\right)\end{array}$ & $\begin{array}{c}\mathbf{d}_{50} \mathbf{Q} \\
\text { initial } \\
{\left[\mathrm{m}^{3} / \mathrm{s}\left(\mathrm{ft}^{3} / \mathrm{s}\right)\right]}\end{array}$ & $\begin{array}{c}d_{50} \tau_{c} \\
\text { complete } \\
\left(\mathrm{N} / \mathrm{m}^{2}\right)\end{array}$ & $\begin{array}{c}d_{50} Q \\
\text { complete } \\
{\left[\mathrm{m}^{3} / \mathrm{s}\left(\mathrm{ft}^{3} / \mathrm{s}\right)\right]}\end{array}$ & $\begin{array}{l}\text { Return period } \\
\text { for initial } \\
\text { entrainment of } d_{50} \\
\text { (yr) }\end{array}$ & $\begin{array}{l}\text { Return period } \\
\text { for complete } \\
\text { entrainment of } d_{50} \\
(y r)\end{array}$ \\
\hline \multirow{3}{*}{1} & \multirow{3}{*}{$\begin{array}{l}\text { North Llano River } \\
\text { near Junction }\end{array}$} & 0 & 22.99 & $21.9(774)$ & 45.98 & $82.3(2,910)$ & $<1$ & $<1$ \\
\hline & & 2 & 22.99 & $71.6(2,530)$ & 45.98 & $302(10,600)$ & $<1$ & 1.4 \\
\hline & & 3 & 22.99 & $29.2(1,030)$ & 45.98 & $123(4,340)$ & $<1$ & $<1$ \\
\hline \multirow{3}{*}{2} & \multirow{3}{*}{$\begin{array}{l}\text { Johnson Fork at Low- } \\
\text { lands Crossing }\end{array}$} & 1 & 27.03 & 9.44 (333) & 54.07 & $91.7(3,240)$ & $<1$ & 2.0 \\
\hline & & 2 & 27.03 & $22.0(776)$ & 54.07 & $140(4,930)$ & 1.5 & 2.2 \\
\hline & & 3 & 27.03 & $16.3(575)$ & 54.07 & $227(8,030)$ & 1.1 & 2.4 \\
\hline \multirow{2}{*}{3} & \multirow{2}{*}{$\begin{array}{l}\text { Llano River near } \\
\text { Junction }\end{array}$} & 2 & 18.87 & $.70(24.9)$ & 37.74 & $3.66(129)$ & $<1$ & $<1$ \\
\hline & & 3 & 18.87 & $5.38(190)$ & 37.74 & $104(3,660)$ & $<1$ & $<1$ \\
\hline \multirow{2}{*}{4} & \multirow{2}{*}{$\begin{array}{l}\text { Llano River near Ivy } \\
\text { Chapel }\end{array}$} & 2 & 16.47 & $123(4,340)$ & 32.95 & $515(18,200)$ & $<1$ & 1.3 \\
\hline & & 3 & 16.47 & $101(3,550)$ & 32.95 & $429(15,200)$ & $<1$ & 1.2 \\
\hline
\end{tabular}

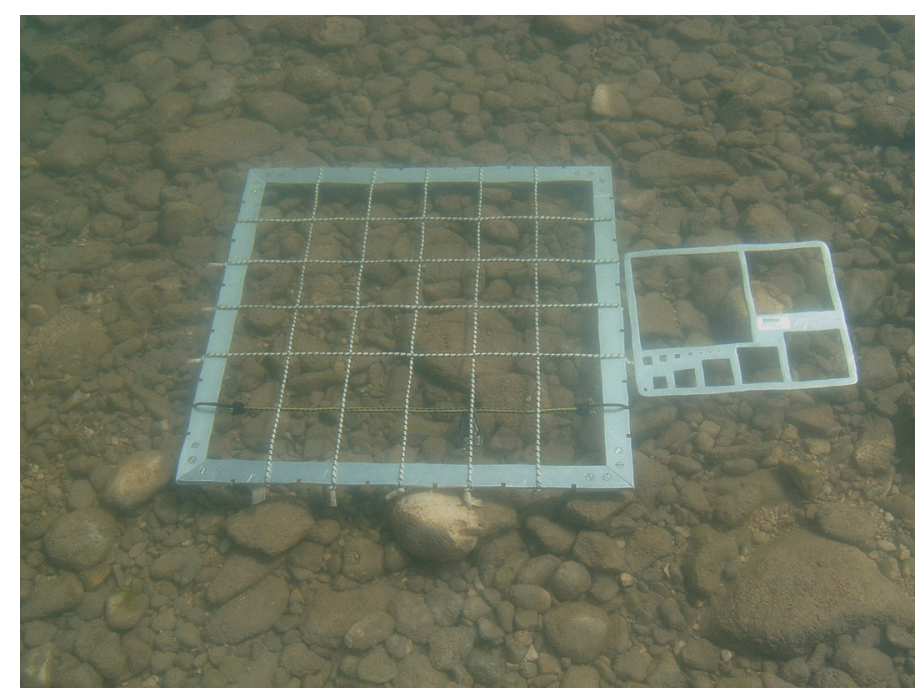

Figure 5. Underwater sampling grid and particle-size analyzer on gravel and cobble bed of South Llano River, Kimble County, Texas.

\section{Reference}

\section{This fact sheet is based on the following USGS report:}

Heitmuller, F.T., and Asquith, W.H., 2008, Potential for bedmaterial entrainment in selected streams of the Edwards Plateau-Edwards, Kimble, and Real Counties, Texas, and vicinity: U.S. Geological Survey Scientific Investigations Report 2008-5017, 76 p.

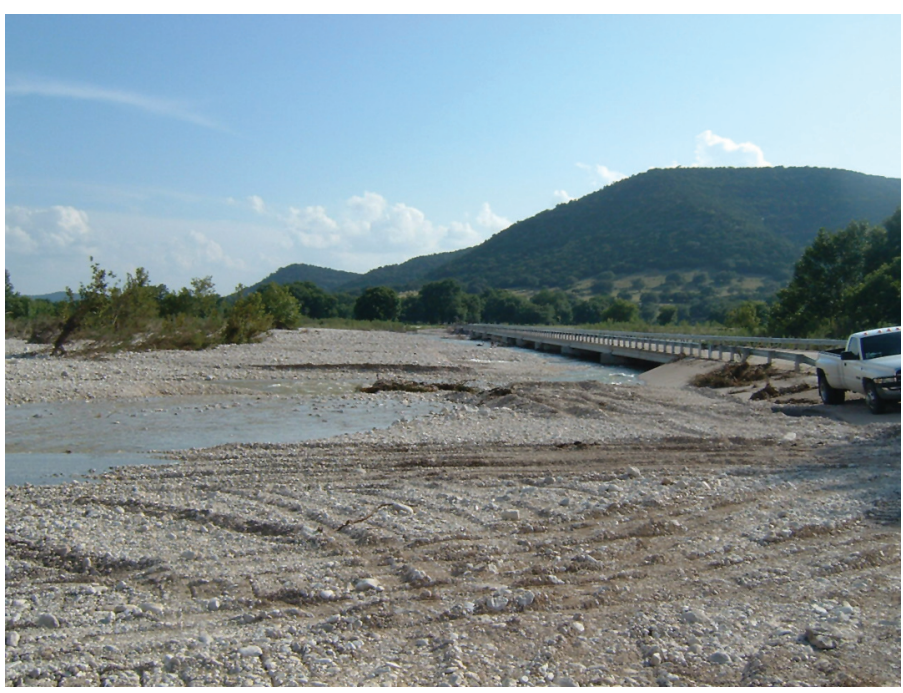

Figure 6. Nueces River at Vance Crossing, Edwards-Real County line, Texas. Cobble- and gravel-sized bed material clogs the channel and undergoes substantial reconfiguration during high flows.

Any use of trade, product, or firm names is for descriptive purposes only and does not imply endorsement by the U.S. Government.

Information on technical reports and hydrologic data related to this study can be obtained from:

Director

USGS Texas Water Science Center

World Wide Web: http://tx.usgs.gov/

E-mail: gs-w-txpublic-info@usgs.gov 